\title{
Diversity of Cerambycidae (Insecta: Coleoptera) in the Cerrado of Central Brazil using a new type of bait
}

\author{
Juliane Evangelista ${ }^{1}$, Marcus Vinicius Celani Rocha ${ }^{1}$, Marcela Laura Monné ${ }^{\circledR}$, Miguel Angel Monné $e^{\circledR}$ \\ Marina Regina Frizzas ${ }^{1 *}$ \\ ${ }^{1}$ Universidade de Brasília, Instituto de Ciências Biológicas, Departamento de Zoologia, Campus Darcy Ribeiro, \\ CEP 70910-900, Brasília, DF, Brasil. \\ ${ }^{2}$ Universidade Federal do Rio de Janeiro, Museu Nacional, Departamento de Entomologia, Quinta da Boa \\ Vista, São Cristóvão, CEP 20940-040, Rio de Janeiro, RJ, Brasil. \\ ${ }^{2}$ Corresponding author: Marina Regina Frizzas, e-mail:frizzas@unb.br
}

EVANGELISTA, J., ROCHA, M.V.C., MONNÉ, M.L., MONNÉ, M.A., FRIZZAS, M.R. Diversity of Cerambycidae (Insecta: Coleoptera) in the Cerrado of Central Brazil using a new type of bait. Biota Neotropica 21(1): e20201103. https://doi.org/10.1590/1676-0611-BN-2020-1103

\begin{abstract}
The Cerambycidae family (Insecta: Coleoptera) has approximately 38 thousand species. In Brazil, more than 4,300 species and 1,050 genera are registered, and despite the ecological and agricultural importance of this family, no study has yet been done in the Cerrado of the Distrito Federal (Brazil). The objective of this study was to evaluate the richness and abundance of Cerambycidae in the Cerrado area using two types of fruits (banana and pineapple), fermented with sugarcane juice, as bait and to verify whether the richness is influenced by climate variables. The work was carried out in an area of the cerrado sensu stricto at Água Limpa Farm in the Distrito Federal. Beetles were collected weekly using 40 bait traps with two types of fruits that remained in the field for 12 uninterrupted months (November 2013 to October 2014). The traps were installed $1.50 \mathrm{~m}$ above the ground level, distributed in four $80 \mathrm{~m}$ transects, and spaced $20 \mathrm{~m}$ apart. A total of 1,599 individuals, belonging to 13 genera and different 19 species, were collected. The main species were as follows: Oxymerus basalis (Dalman, 1823) representing 78.3\%, Retrachydes thoracicus thoracicus (Olivier, 1790) representing 9.9\%, and Chydarteres bicolor (Fabricius, 1787) representing $4.5 \%$ of the total specimens collected. There was a significant difference in richness and abundance of Cerambycidae among the baits evaluated, with the pineapple bait presenting the highest values. The greatest number of individuals and species occurred soon after the first rains, especially in November. Temporal variation was confirmed through Rayleigh's uniformity test, following the seasonality of the Cerrado, with the greatest number of individuals and species found in the rainy season. Temperature and humidity influenced the richness of cerambycid beetles. This is the first work carried out with pineapple fermented with sugarcane juice as bait to capture Cerambycidae, and this type of bait proved to be efficient for the collection of insects, comparable in efficiency to the synthetic baits that are normally used. All species collected were new distribution records for the Distrito Federal (Brazil).
\end{abstract}

Keywords: Fermented fruit; Climate variables; Baited trap; Longhorn beetles; New records.

\section{Diversidade de Cerambycidae (Insecta: Coleoptera) no Cerrado do Brasil Central utilizando um novo tipo de isca}

\footnotetext{
Resumo: A família Cerambycidae (Insecta: Coleoptera) possui aproximadamente 38 mil espécies. No Brasil são registradas mais de 4.300 espécies e 1.050 gêneros e, apesar da importância ecológica e agrícola desta família, ainda não foram realizados trabalhos no Cerrado do Distrito Federal. O objetivo deste trabalho foi avaliar a riqueza e abundância de Cerambycidae utilizando dois tipos de frutas (banana e abacaxi) fermentadas com caldo de cana em área de cerrado e verificar se a riqueza é influenciada pelas variáveis climáticas. O trabalho foi realizado em uma área de cerrado sensu stricto na Fazenda Água Limpa (FAL) em Brasília, Distrito Federal. A coleta de adultos de Cerambycidae foi realizada semanalmente usando 40 armadilhas iscadas com os dois tipos de frutas que ficaram em campo por 12 meses ininterruptos (novembro de 2013 a outubro de 2014). As armadilhas foram instaladas a
} 
Evangelista J. et al.

1,50 m do nível do solo, distribuídas em quatro transectos de $80 \mathrm{~m}$ e espaçadas $20 \mathrm{~m}$ entre si. Foram coletados 1.599 indivíduos, 13 gêneros e 19 espécies. As principais espécies foram Oxymerus basalis (Dalman, 1823) com $78,3 \%$ do total de espécimes coletado, Retrachydes thoracicus thoracicus (Olivier, 1790) com 9,9\% e Chydarteres bicolor (Fabricius, 1787) com 4,5\%. Houve diferença significativa na riqueza e abundância de Cerambycidae entre as iscas avaliadas, sendo a isca de abacaxi a que apresentou os maiores valores. O maior número de indivíduos e de espécies ocorre logo após as primeiras chuvas, principalmente no mês de novembro. A variação temporal foi confirmada através do teste de uniformidade de Rayleigh que acompanha a sazonalidade do Cerrado, com maior número de indivíduos e de espécies na estação chuvosa. A temperatura e umidade são as variáveis climáticas que influenciaram a riqueza de cerambicídeos. Este é o primeiro trabalho realizado com abacaxi fermentado com caldo de cana para captura de Cerambycidae, e este tipo de isca se mostrou eficiente para a coleta dos insetos, podendo ser comparado com as iscas sintéticas que normalmente são utilizadas. Todas as espécies coletadas são novos registros de distribuição para o Distrito Federal.

Palavras-chave: Fruta fermentada; Variáveis climáticas; Armadilha iscada; Serra pau; Novos registros.

\section{Introduction}

Cerambycidae (Insecta: Coleoptera) is a cosmopolitan family with more than 38,000 described species (Tavakilian \& Chevillotte 2020); in the Neotropical Region, more than 8,000 species in 1,550 genera have been described (Monné 2020a). More than 800 species of Cerambycidae are registered for the Cerrado (Monné 2020b). They are phytophagous insects, with xylophagous larvae that feed on roots, logs, and branches of young rotting trees (Arnett et al. 2002, Marinoni et al. 2003) and adults that feed on wood, roots, leaves, pollen, sap, and fruits.

Adults are known as longhorn beetles because most have very long antennae (Galileo \& Martins 2006), many times longer than their body length. The antennae serve as olfactory organs for locating host plants suitable for oviposition (Bezark \& Monné 2013). They are known by the popular name of "serra pau" in Brazil because some species (eg Onciderini) have the habit of sawing the logs and branches of trees, for oviposition. This habit damages forests and agricultural areas, leading to the beetles being considered pests of perennial plants, such as fruit trees and forest species, where their larvae feed on logs, branches, and roots, forming galleries, with some species existing in their larval stage for as long as 10 years (Galileo \& Martins 2006, Silva et al. 2016). Regarding their time of activity, some species are considered nocturnal and are found in their host plants, and others are diurnal, are attracted by flowers and act as pollinators (Bezark \& Monné 2013).

There are hundreds of papers published in Brazil on the Cerambycidae family, addressing topics such as species diversity (Maia et al. 2003, Napp \& Monné 2006, Souza \& Silva 2012), genera review (Monné \& Monné 2006), species seasonality (Marinoni \& Ganho 2003), and ecological and behavioral aspects (Machado et al. 2006, Lemes et al. 2011). Despite some studies in the Goiás region (Canettieri \& Garcia 2000) and in RPPN Santuário do Caraça, Minas Gerais (Monné \& Monné 2017), few studies have been carried out in Central Brazil within the Cerrado biome.

The Cerrado is the second largest biome of Brazil, with about 2 million $\mathrm{km}^{2}$ (Klink \& Machado 2005, Prevedello \& Carvalho 2006); it is considered a biodiversity hotspot and is an area of conservation priority (Myers et al. 2000, Mittermeier et al. 2005, Sano et al. 2010). This tropical savanna presents several types of phytophysiognomies, with a vegetation gradient that passes through herbaceous formations, grasses, shrubs, and forests, presenting differentiated microclimates and a variation in food resource availability.
It has two well-defined seasons: dry (April to September) and rainy (October to March), with an average annual precipitation of $1,500 \mathrm{~mm}$ and large intra-regional variations (Silva et al. 2008). This seasonality has a great influence on vegetation, decreasing or increasing resources, which generate alternation in the abundance of insects (Oliveira \& Frizzas 2008, Becerra et al. 2009). In regions where the dry season is well defined, insect abundance tends to be smaller because it is synchronized with resource availability and climate (Wolda 1978, Pinheiro et al. 2002, Silva et al. 2011).

The biome presents a diversity of habitats that facilitates the distribution of organisms in different environments (Sano et al. 2010). However, it has constantly suffered from anthropogenic actions, such as severe losses and fragmentation of native areas due to agricultural activities (Klink \& Machado 2005), which has led to reductions in ecosystem services provided by the Cerrado and its diverse inhabitants (Tilman et al. 2002). Despite the services that the insects provides, such as pollination, decomposition, and biological control of pests (Ramos et al. 2020), cerambycid beetles have been negatively affected by deforestation caused by timber extraction and agricultural activity (IUCN 2019). A study conducted in Australia showed that the Cerambycidae community is influenced by burning regimes, which promote habitat alteration; the study showed that burned areas had a greater richness of beetles than unburned areas, and that the abundance of beetles in areas burned triennially was greater than that in unburned areas (Eliott et al. 2019). The Cerrado is a biome closely linked to fire, and if the Cerambycidae community in Central Brazil follows the pattern found in Australia, it should also be affected by this factor.

Previous studies with Cerambycidae have used different sampling methods, the main ones being sweeping foliage, manual collections, sticky cards (Sakalian \& Georgiev 2011), attraction to light (Canettieri \& Garcia 2000), pheromone (Hanks et al. 2012), fermented bait (Schmeelk et al. 2016), malaise trap (Maia et al. 2003), bait traps with synthesized chemical compounds (Wong \& Hanks 2016), and, in some cases, flight interception traps and pitfalls (Bezark \& Monné 2013).

The bait traps have proven to be a very efficient sampling method for Cerambycidae (Schmeelk et al. 2016). However, there are a variety of bait types that can be used. Studies using alcohol and chemical compound mixes (Fernandes et al. 2010, Alisson et al. 2019), and fermented material mixes containing fungi, wood, banana, sugar, molasses, and beer (Schmeelk et al. 2016, Wong \& Hanks 2016) as 
baits have already been performed. In Brazil, studies have mainly used sugarcane molasses as fermented baits, with $20 \%$ sugarcane molasses (Garcia 1987) and 10\% honey (Santos et al. 2014), to test their attractiveness to borer (Garcia \& Nakano 1984) and cerambycid beetles. The use of sugarcane molasses or sugarcane juice mixed with ripe fruit has also been implemented for the collection of other Coleoptera families (Pacheco et al. 2006, Jákl 2009, Orozco 2012, Evangelista Neto et al. 2017) as well as for other orders of insects (Zacca \& Bravo 2012).

The objectives of this study were to evaluate the richness and abundance of Cerambycidae using two types of fruits (banana and pineapple) fermented with sugarcane juice as baits in an area of cerrado sensu stricto and to verify whether the richness of Cerambycidae is influenced by climatic variables (temperature, humidity, and precipitation). Our hypothesis is that although most fermented baits use bananas in their composition, pineapple fermentation produces more ethanol than banana fermentation, suggesting a higher sugar concentration (Hajar et al. 2012); therefore, with the use of sugarcane juice to enhance fruit fermentation, it is expected that the combination of sugarcane juice with pineapple will present more fermentation and will be more attractive to cerambycid beetles than the combination of sugarcane juice and banana. It is also expected that with the alternation of the dry and rainy season, the availability of fruits and flowers as well as other resources will vary, regulating the populations of these insects and causing seasonality in this group of organisms.

\section{Material and Methods}

\section{Study area}

The study was conducted at the Água Limpa Farm (FAL) belonging to the University of Brasília - UnB, Distrito Federal (Brazil). The FAL is a part of the Protection Area (APA) of the "Gama" and "Cabeça do Veado" basins (15 $56^{\circ}$ ' to $15^{\circ} 59^{\prime} \mathrm{S}$ and $47^{\circ} 55^{\prime}$ ' to $47^{\circ} 58^{\prime}$ ' $\mathrm{W}, 1,096 \mathrm{~m}$ ) comprising an area of 4,500 ha. The Cerrado biome has an environmental heterogeneity that favors the diversified occurrence of phytophysiognomies. Consequently, both floristic and faunistic diversity are very high and include endemic plant and animal species (PELD 2018). The study was carried out in an area of cerrado sensu stricto, a phytophysiognomy characteristic of the biome, presenting low, tortuous plants - with thick bark logs and rigid leaves - that range from 1.5 to $5 \mathrm{~m}$ in height, demonstrating adaptations to the dry season during which fires usually occur, representing $70 \%$ of the biome (Felfili \& Silva Júnior 2005).

Climatic data, including temperature, humidity, and precipitation, were obtained throughout the study period through the AgroClimatic Bulletin provided by the Faculty of Agronomy and Veterinary Medicine of the University of Brasília (FAV/UnB).

\section{Cerambycidae sampling}

The sampling of adults was carried out weekly for 12 months, from November 2013 to October 2014, using 40 bait traps that remained uninterrupted in the field. The traps consisted of a $2-\mathrm{L}$ cylindrical plastic bottle with three $8 \times 8 \mathrm{~cm}$ side windows located $10 \mathrm{~cm}$ above the base. Baits $(150 \mathrm{~mL})$, either consisting of banana (variety Dwarf Cavendish) or pineapple fermented for $48 \mathrm{~h}$ in sugarcane juice, were placed in each trap, according to Rodrigues et al. (2013) and Puker et al. (2014). Banana baits were used in half of the traps and pineapple baits in the other half. The traps were placed in trees, about $1.5 \mathrm{~m}$ above ground level, distributed along four $80 \mathrm{~m}$ transects and spaced $20 \mathrm{~m}$ apart. Each transect was marked at a minimum of $20 \mathrm{~m}$ from the point of entry of the experimental area to avoid possible margin effects and traps were placed thereafter.

After collection, the insects were taken to the Coleoptera Biology and Ecology Laboratory of the University of Brasilia, and the cerambycid beetles were separated from the other insects. Species were identified by one of the authors (MAM, National Museum/Federal University of Rio de Janeiro). Vouchers of the collected material were deposited in the Entomological Collection of the Department of Zoology of the University of Brasilia (DZUB).

\section{Data analysis}

The experimental design had pseudoreplication. Therefore, Rayleigh's uniformity test, which analyzes the functional relationship of variables under the concept of dimensional homogeneity (Mendoza 1994), was used to analyze temporal variation data. Circular analysis was used to evaluate the abundance and richness of Cerambycidae in different months of the year. To compare the abundance and richness of Cerambycidae with regard to the bait types used, a t-test was performed. To verify if the richness was influenced by climatic variables (temperature, humidity, and precipitation), Kruskal-Wallis and MannWhitney tests were performed with Bonferroni correction. To verify the sampling effort efficiency in relation to the survey and the diversity of Cerambycidae, species rarefaction curves were constructed based on the number of samples and number of individuals, using the Chao 1 index and 1,000 randomizations. All analyses were performed using Past 3.20 (Hammer et al. 2001) and Oriana (Kovach 2011).

\section{Results}

A total of 1,599 specimens, with 19 species belonging to 13 genera and five tribes, were collected. The species with the highest abundance were as follows: Oxymerus basalis (Dalman, 1823) comprising 78.3\% of the total specimens collected, Retrachydes thoracicus thoracicus (Olivier, 1790) comprising 9.9\%, and Chydarteres bicolor (Fabricius, 1787) comprising $4.5 \%$.

In the pineapple bait traps, 1,013 individuals, consisting of 18 species belonging to 13 genera, were collected. In the banana bait traps, 586 individuals, consisting of 11 species belonging to six genera, were collected. There were significant differences in the richness $(\mathrm{t}=3.7422$; $\mathrm{p}<0.05)$ and abundance $(\mathrm{t}=1.7237 ; \mathrm{p}<0.0005)$ of Cerambycidae between the two types of baits evaluated. Ten different species were collected from the two types of baits, and the species Coleoxestia waterhousei (Gounelle, 1909); Drychateres bilineatus (Olivier, 1795); Eburodacrys crassimana Gounelle, 1909; Eurysthea hirta (Kirby, 1818); Juiaparus mexicanus (Thomson, 1861); Lissonotus spadiceus Dalman, 1823; Oxymerus aculeatus aculeatus Dupont, 1838; and Plocaederus confusus Martins \& Monné, 2002, were collected only in the pineapple bait, whereas one species, Sphallotrichus setosus (Germar, 1823), was collected only in the banana bait (Table 1). 
Evangelista J. et al.

Table 1. Species and abundance of Cerambycidae collected in baited traps with fermented fruits in the dry and rainy seasons at Água Limpa Farm in the cerrado sensu stricto in Brasília-DF, Brazil, from November 2013 to October 2014.

\begin{tabular}{|c|c|c|c|c|c|}
\hline Species & Tribe & Pineapple & Banana & Dry & Rainy \\
\hline Chydarteres bicolor (Fabricius, 1787) & Trachyderini & 49 & 23 & - & 72 \\
\hline Chydarteres octoliwneatus (Thunberg, 1822) & Trachyderini & 07 & 02 & - & 09 \\
\hline Chydarteres striatus striatus (Fabricius, 1787) & Trachyderini & 02 & 02 & - & 04 \\
\hline Drychateres bilineatus (Olivier, 1795) & Trachyderini & 01 & - & - & 01 \\
\hline Eburodacrys crassimana Gounelle, 1909 & Eburiini & 02 & - & - & 02 \\
\hline Eurysthea hirta (Kirby, 1818) & Elaphidiini & 01 & - & 01 & - \\
\hline Juiaparus mexicanus (Thomson, 1861) & Cerambycini & 02 & - & - & 02 \\
\hline Oxymerus luteus luteus (Voet, 1778) & Trachyderini & 01 & 01 & - & 02 \\
\hline Plocaederus confusus Martins \& Monné, 2002 & Cerambycini & 02 & - & - & 02 \\
\hline Retrachydes thoracicus thoracicus (Olivier, 1790) & Trachyderini & 116 & 39 & 84 & 71 \\
\hline Sphallotrichus sericeotomentosus Fragoso, 1995 & Cerambycini & 01 & 01 & - & 02 \\
\hline Sphallotrichus setosus (Germar, 1823) & Cerambycini & - & 01 & - & 01 \\
\hline Trachyderes succinctus succinctus (Linnaeus, 1758) & Trachyderini & 36 & 31 & 01 & 66 \\
\hline Total & 5 & 1,013 & 586 & 87 & 1,512 \\
\hline
\end{tabular}

Cerambycid beetles were collected during all months of the year. The highest abundance (1,171 individuals) and richness (14 species) were observed in November, while the lowest abundance (one individual) and richness (one species) were observed in September (Figure 1). In the rainy season, 1,512 individuals ( $94.5 \%$ of the total), comprising 17 species, were collected. In the dry season, 87 individuals (5.4\% of the total), comprising four species, were collected (Table 1). With the exception of $R$. thoracicus thoracicus, which was collected throughout the year, most species were collected during the rainy season.

April represents the period of transition between the rainy and dry seasons, and showed a small peak in abundance. During this period, 62 individuals, comprising two species, were collected. Eurysthea hirta and O. aculeatus aculeatus were collected only in the dry season. Circular data analysis showed similarity in the richness and abundance of Cerambycidae and that there was a seasonal distribution for the family, with abundance and richness peaks occurring in November (Figure 2). Abundance presented a well-defined peak in November, whereas richness was more evenly distributed throughout the year, but still showed higher concentration in the rainy season (Figure 2). Rayleigh's uniformity test showed that there was significant temporal variation in the abundance and richness of Cerambycidae $(\mathrm{P}<0.0001)$.

It was observed that climate variables were correlated with the richness of Cerambycidae, but only temperature and humidity had statistical significance on richness (Table 2). Species rarefaction curves, based on the number of samples and the number of individuals observed, indicated that the sampling effort would need to be greater to better characterize the local community of Cerambycidae attracted by fermented fruit baits (Figure 3).
We registered the following species for the first time for the Distrito Federal (Brazil): Chydarteres bicolor, Chydarteres dimidiatus dimidiatus (Fabricius, 1787), Chydarteres octolineatus (Thunberg, 1822), Chydarteres striatus striatus (Fabricius, 1787), Coleoxestia waterhousei, Dorcacerus barbatus (Olivier, 1790), Drychateres bilineatus, Eburodacrys crassimana, Eurysthea hirta, Juiaparus mexicanus, Lissonotus spadiceus, Oxymerus aculeatus aculeatus, Oxymerus basalis, Oxymerus luteus luteus (Voet, 1778), Plocaederus confusus, Retrachydes thoracicus thoracicus, Sphallotrichus sericeotomentosus Fragoso, 1995, Sphallotrichus setosus, and Trachyderes succinctus succinctus (Linnaeus, 1758).

\section{Discussion}

In Brazil, the Cerambycidae family is represented by more than 1,050 genera and 4,300 species (Monné 2020a). In the present study, 13 genera and 19 species were collected in the cerrado sensu stricto, an area with the characteristic phytophysiognomy of the Cerrado biome. The diversity found in this study was low in comparison to other studies that have been done with the family in other biomes (Maia et al. 2003, Souza \& Silva 2012, Ferreira \& Rocha 2015, Monné \& Monné 2017). A possible explanation for the low diversity found in the study, since more than 800 species are reported for the biome, is that we use only one type of trap. Other studies use more than one type of trap such as malaise, light trap, flight interception, trap with pheromones at different heights (Canettieri \& Garcia 2000, Maia et al. 2003, Bezark \& Monné 2013, Wong \& Hanks 2016, Barros et al. 2020). Although, another 
(A)

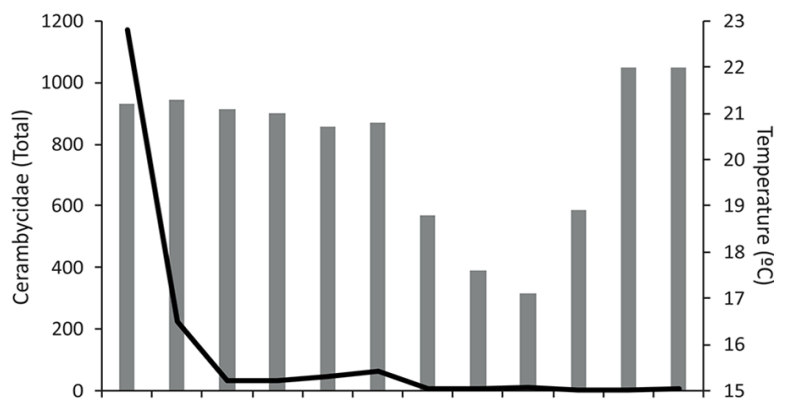

(B)

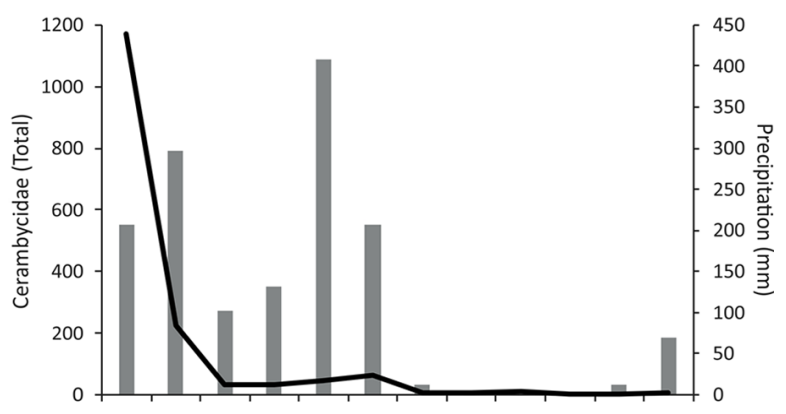

(C)

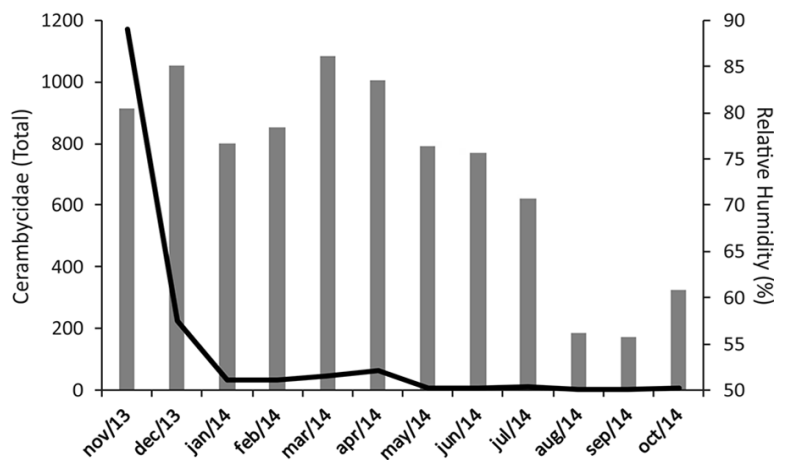

Figure 1. Average temperature $\left({ }^{\circ} \mathrm{C}\right)$, precipitation $(\mathrm{mm})$, relative humidity $(\%)$, and abundance of Cerambycidae collected in baited traps with fermented fruits at Água Limpa Farm in Brasília-DF, Brazil, from November 2013 to October 2014.

study carried out in the biome with bait traps has found only 13 species of Cerambycidae (Santos et al. 2014). The Cerrado has environmental heterogeneity which leads to diverse phytophysiognomies, presenting high floristic diversity and endemic plant species. The plants are low, tortuous, with thick bark logs and rigid leaves that can be from 1.5 to $5 \mathrm{~m}$ in height, showing adaptations to the dry season (Felfili \& Silva Júnior 2005). Cerambycidae have a close relationship with their host plants and, despite the floristic diversity of the biome, many plant species may not be suitable hosts for Cerambycidae.

The diversity of Cerambycidae collected on pineapple bait differed statistically from banana bait in that 427 individuals and eight more species were collected on pineapple bait. Cerambicids are mostly collected with traps using alcohol-based baits, and greater abundance and richness was found when using the fermented pineapple bait. It is assumed that the fermentation of this fruit with sugarcane juice presents a greater volatilization of alcohols. In addition, pineapple possibly has higher amounts of sugars than banana, since in the fermentation of these two fruits, the alcoholic content of the banana (variety Dwarf Cavendish) is $0.035 \%(\mathrm{w} / \mathrm{v})$, while that of the pineapple is $0.21 \%(\mathrm{w} / \mathrm{v})$ (Hajar et al. 2012). Thus, pineapple has an alcohol content six times higher than
(A)

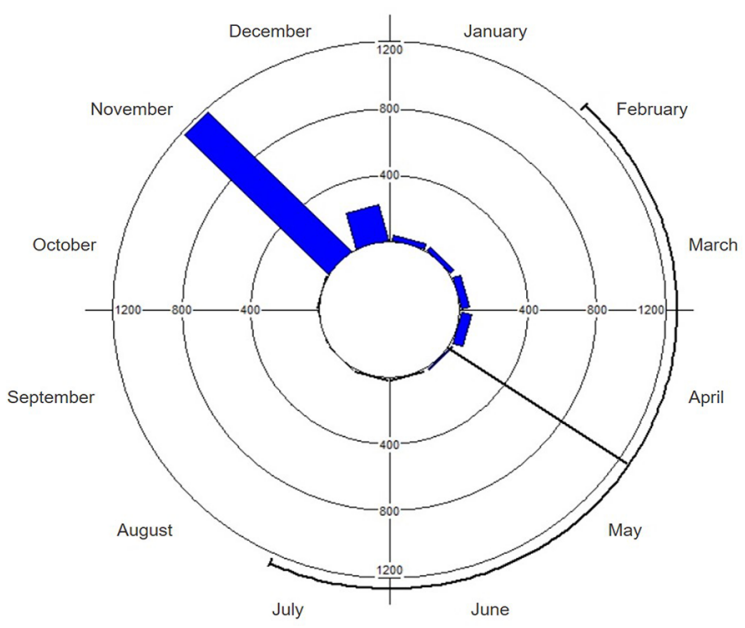

(B)

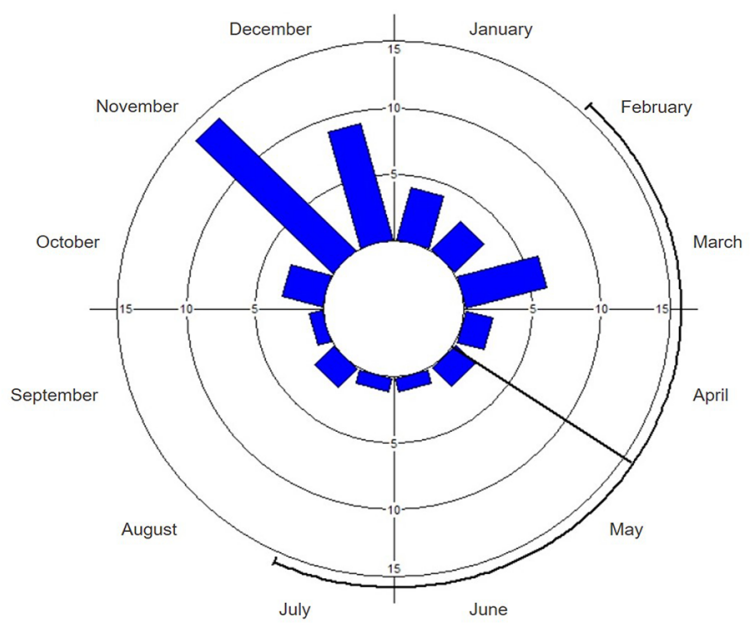

Figure 2. Circular analysis for (A) abundance and (B) richness of Cerambycidae collected in baited traps with fermented fruits at Água Limpa Farm in BrasíliaDF, Brazil, from November 2013 to October 2014.

banana, and this factor may have resulted in the greater attractiveness of the fermented pineapple when used as bait for the Cerambycidae community. This is the first work performed with fermented pineapple with sugarcane juice to capture Cerambycidae, and this type of bait proved to be efficient for the collection of insects and may be a promising bait for future studies with this group.

The sampled community follows the usual neotropical pattern, where there are a large number of rare and few dominant species (Antonelli et al. 2018). The two species that represented more than $90 \%$ of the collection were $O$. basalis and $R$. thoracicus thoracicus.

In this study, $O$. basalis dominated the assembly (representing $78.3 \%$ of the collected individuals), indicating that this is probably a species more adapted to the biome. The larvae of $O$. basalis make holes of about $1 \mathrm{~mm}$ in eucalyptus trees and can build galleries $50 \mathrm{~cm}$ in length inside the plant (Zanuncio et al. 2009). Besides eucalyptus, other genera of Myrtaceae occur in the Cerrado (Conceição \& Aragão 2010), and these plants are possibly used as a resource by $O$. basalis, allowing their populations to establish themselves and reach expressive densities. Gottsberger (1988) reported O. basalis as a pest on Annona coriacea Mart. This species, in Brazil, has a wide distribution (Monné 2020a). 
Evangelista J. et al.

Table 2. Mann-Whitney test with Bonferroni correction for correlation between climatic variables and Cerambycidae richness for beetles collected with baited traps with fermented fruits at Água Limpa Farm in Brasília-DF, Brazil, from November 2013 to October 2014. The highlighted values represent a significant relationship between the variables.

\begin{tabular}{lcccc}
\hline Variables & Temperature & Precipitation & Humidity & Richness \\
\hline Temperature & - & 1 & 0.0002187 & 0.0002111 \\
Precipitation & 1 & - & 1 & 0.05092 \\
Humidity & 0.0002187 & 1 & - & 0.0002119 \\
Richness & 0.0002111 & 0.05092 & 0.0002129 & - \\
\hline
\end{tabular}

\section{(A)}

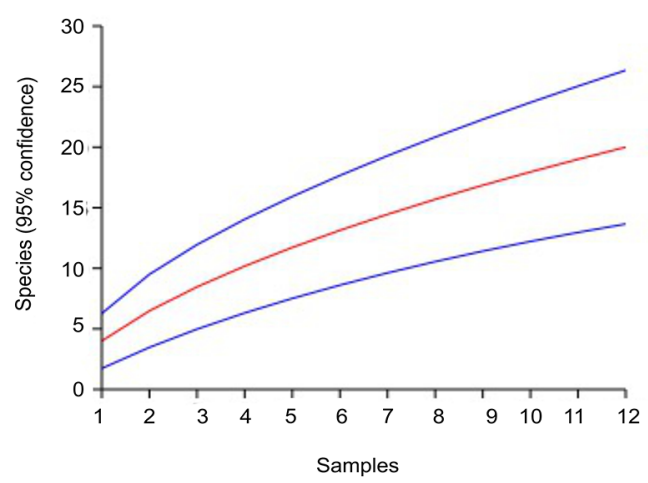

(B)

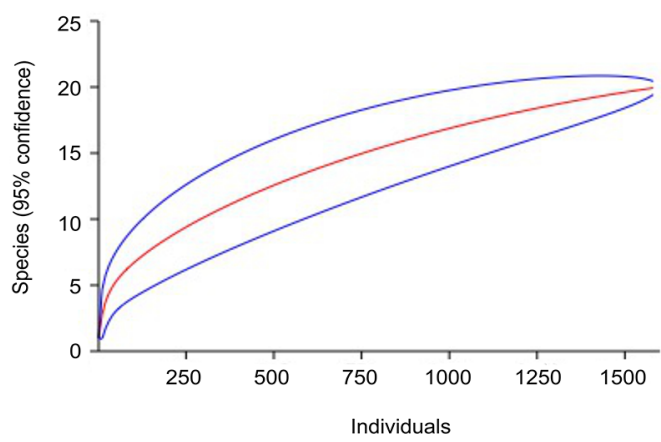

Figure 3. Rarefaction curves of Cerambycidae species collected in baited traps with fermented fruits at Água Limpa Farm in Brasília-DF, Brazil, from November 2013 to October 2014. Bars below and above the curves indicate standard deviations. (A) Curve created based on monthly samples collected for 12 months and (B) Curve created based on the collected 1,599 individuals.

Retrachydes thoracicus was the second most collected species $(9.9 \%)$, and the only species found during all the year. It has several records of host plants (Monné 2020a) and is considered a pest of plants of the Fabaceae (Costa et al. 2019), Moraceae, Ulmaceae (Di Iorio 1997), and Salicaceae (Machado et al. 2012) families, and its larvae damage the species Litchi chinensis Sonn. (Casari \& Albertoni 2017). This species occurs in Bolivia, Paraguay, Argentina, Uruguay and Brazil, in the northeastern (except Sergipe), midwestern (except Distrito Federal), southeastern, and southern regions (Monné 2020a, b).

In this study five tribes of Cerambycidae were found, Trachyderini being the most abundant tribe, representing $99.2 \%$ of the total collected (Table 1). Representatives of this tribe are very attracted by fermented baits, which may explain the result of this study. However, it is worth noting that the abundance of Trachyderini depends on the place of collection and the bait used, in other areas of Cerrado we found species of distinct genera, being 39 species of Trachyderini reported for the Cerrado biome. The species collected belong to the subfamily
Cerambycinae, something expected since the traps with fermented baits normally are used to collect diurnal species. The other subfamilies of Cerambycidae, except Lepturinae, are usually nocturnal, therefore not attracted by this type of trap.

The temporal variation in the abundance and richness of Cerambycidae is directly related to the climatic characteristics of the Cerrado, with the largest number of individuals and species occurring in the rainy season (Figure 3). Rainfall distribution is a factor that influences changes in temperature and relative humidity, and indirectly affects plant growth, the main food resource of herbivorous insects (Oliveira \& Frizzas 2008, Silva et al. 2011). The biome has two well-defined climatic seasons, with the rainy season that occurs from October to March, where most adult insect populations are concentrated (Silva et al. 2011), a fact also verified for the Cerambycidae family in the Cerrado, which presented $94.5 \%$ of individuals and $90 \%$ of collected species in the rainy season. The greater diversity (abundance and richness) of adults of Cerambycidae in the rainy season is probably due to the greater availability of food (leaves, fruits, and flowers) in the Cerrado during this period.

Seasonal distribution was observed for the family in the Cerrado, with peak abundance and richness in November, i.e., in the first half of the rainy season. The beginning of the rains is considered the trigger for the increase in population density; other studies conducted with Coleoptera in the Cerrado have found the same pattern, for example, in the families Cetoniidae (Evangelista Neto et al. 2017), Melolonthidae (Oliveira \& Frizzas 2017), and Scarabaeidae (Frizzas et al. 2020).

Although precipitation is one of the most important abiotic factors, temperature and humidity were shown to have significant effects on the richness of Cerambycidae (Table2). Temperature is one of the climatic variables that most influences the activity of many species of insects, determining the development rates of immature animals and the reproductive activity of adults.

Besides having observed a low richness (19 species), it was also observed that the rarefaction curves did not reach the asymptote, indicating the need for further study in the area. Other studies, performed with pheromone baits and fermented baits, obtained a higher abundance (sixfolds as high compared to our study) of cerambycid beetles, in addition to demonstrating that traps at different heights could capture different species, as some species were captured at a specific height and were absent from other treatments (Schmeelk et al. 2016). Thus, this may be an explanation for the rarefaction curve not having reached the asymptote, since the present study used only fermented fruit as bait, and all traps were installed at the same height. Other types of bait and more kind of traps, in addition to having traps at different heights, will probably help obtain a more complete sampling of the Cerambycidae community.

Because it has distinct phytophysiognomies, the Cerrado presents a great diversity of habitats with varied vegetation coverage, moisture retention, food resources, and differentiated reproductive conditions. The species living in the Cerrado, a biome of high biodiversity and one with the most threatened 
species in the world (Mittermeyer et al. 2005), illustrate the possibility of knowing the organisms that compose it to assist in conservation policies and land use destinations. Considering that the present study was conducted only in the cerrado sensu stricto, there is a need for other studies to be carried out in other phytophysiognomies so that more species are registered for the Cerrado. It is important to consider different sampling methods because each group of insects presents variations in alimentary and behavioral habits and, as such, different types of traps can cover the community in a more complete way. On the other hand, sampling techniques should be standardized, since that will make it possible to quantify the richness and abundance of the community in the correct manner (Campos et al. 2000). Although there are few studies addressing fermented fruits in the capture of cerambycid beetles, in the existing studies, only the banana was used as a resource; in the present study, howeverd it was observed that the pineapple has a higher capture efficiency that could be compared with synthetic baits, demonstrating the importance of this type of bait.

All species collected in this study are new records for the Distrito Federal (Brazil). Despite the importance of the Cerambycidae family, there are few studies on this group of organisms in the Cerrado. Studies aimed at documenting and understanding the spatial patterns of biological diversity are of great importance in guiding conservation planning programs (Franklin 2009). This study is of great relevance in terms of public conservation policies, as they can potentially indicate priority sites for conservation, which is highly relevant for the Cerrado as it has suffered systematically from anthropogenic pressures, mainly in relation to deforestation and expansion of agricultural activities, in recent years.

\section{Acknowledgments}

We thank the University of Brasilia and the Graduate Program in Zoology, Coordenação de Aperfeiçoamento de Pessoal de Nível Superior (CAPES) for providing a scholarship for the first author. MRF has CNPq (National Council for Scientific and Technological Development) fellowship (process \# 313952/2018-3). Collecting was done with permits from ICMBio (license \# 41005-1).

\section{Author Contributions}

Juliane Evangelista: contributed substantially to the concept and design of the study, data collection, data analysis and interpretation, and manuscript preparation, including critical revision and addition of intellectual content.

Marcus Vinicius Celani Rocha: contributed to the concept of the study, data collection, data analysis and interpretation, and preparation of the manuscript.

Marcela Laura Monné: contributed to the critical revision, data analysis and interpretation, and addition of intellectual content to the manuscript.

Miguel Angel Monné: contributed to the critical revision, data analysis and interpretation, and addition of intellectual content to the manuscript.

Marina Regina Frizzas: contributed substantially to the concept and design of the study, data interpretation, and manuscript preparation, including critical revision and addition of intellectual content.

\section{Conflicts of interest}

The authors declare that they have no conflicts of interest related to the publication of this manuscript.

\section{References}

ALLISON, J., STROM, B., SWEENEY, J. \& MAYO, P. 2019. Trap deployment along linear transects perpendicular to forest edges: impact on capture of longhorned beetles (Coleoptera: Cerambycidae). J. Pest Sci. 92: 299-308.

ANTONELLI, A., ARIZA, M., ALBERT, J., ANDERMANN, T., AZEVEDO, J., BACON, C., FAURBY, S., GUEDES, T., HOORN, C., LOHMANN, L.G., MATOS-MARAVÍ, P., RITTER, C.D., SANMARTÍN, I., SILVESTRO, D., TEJEDOR, M., TER STEEGE, H., TUOMISTO, H., WERNWCK, F.P., ZIZKA, A. \& EDWADS, S.V. 2018. Conceptual and empirical advances in neotropical biodiversity research. PeerJ 6: e5644.

ARNETT Jr, R.H., THOMAS, M.C., SKELLEY, P.E. \& FRANK, J.H. 2002. American beetles. v. 2. Polyphaga: Scarabaeoidea through Curculionoidea. p. 54-96. CRC. Boca Raton, FL.

BARROS, R.C., FONSECA, M.G., JARDIM, M.T., VENDRAMINI, V.E., DAMIANI, B.C.B. \& JULIO, C.E.A. 2020. Species of Cerambycinae (Insecta, Coleoptera, Cerambycidae) from east Paraná State (Brazil), with new geographic records. Zootaxa 4845(1): 1-25.

BECERRA, J.A.B., SHIMABUKURO, Y.E. \& ALVALÁ, R.C.S. 2009. Relação do padrão sazonal da vegetação com precipitação na região de Cerrado da Amazônia legal, usando índices espectrais de vegetação. Rev. Bras. Meteorol. 24(2): 125-134.

BEZARK, L.G. \& MONNÉ, M.A. 2013. Checklist of the Oxypeltidae, Vesperidae, Disteniidae and Cerambycidae, (Coleoptera) of the Western Hemisphere. http://plant.cdfa.ca.gov/byciddb/checklists/WestHemiCerambycidae2013. pdf (last access in 27/04/2020).

CAMPOS, W.G., PEREIRA, D.B.S. \& SCHOEREDER, J.H. 2000. Comparison of the efficiency of flight-interception trap models for sampling Hymenoptera and other insects. An. Soc. Entomol. Brasil 29(3): 381-389.

CANETTIERI, E.R.P.S. \& GARCIA, A.H. 2000. Abundância relativa das espécies de Cerambycidade (Insecta: Coleptera) em pomar de frutíferas misto. Pesq. Agropec. Trop. 30(2): 43-50.

CASARI, S.A. \& ALBERTONI, F.F. 2017. Immatures of Cerambycinae (Coleoptera, Cerambycidae) collected in Litchi chinensis Sonn. (Sapindaceae) in Brazil. Zootaxa 4254(2): 240-254.

CONCEIÇÃO, G.M. \& ARAGÃO, J.G. 2010. Diversidade e importância econômica das Myrtaceae do Cerrado, Parque Estadual do Mirador, Maranhão. Scient. Plena 6(7): 1-8.

COSTA, M.K.C., DIODATO, M.A., FERNANDES, J.P.P. \& SANTOS, J.P.S. 2019. Insetos nocivos a Prosopis sp. no Rio Grande do Norte (Brasil) e Piura (Peru). Agrop. Cient. Semiárido 15(3): 158-161.

DI IORIO, O.R. 1997. Plantas hospedadoras de Cerambycidae (Coleoptera) en el Espinal periestépico y en la provincia de Buenos Aires, Argentina. Rev. Biol. Trop. 44(3)/45(1): 159-165.

DI IORIO, O.R. 2004. Aporte al catálogo de Cerambycidae del Praguay (Insecta - Coleoptera). Parte IV. Adenda a bosq (Parte I e II) y viana (Parte III). Bol. Mus. Nac. Hist. Nat. Parag. 15(1-2): 9-65.

ELIOTT, M., LAWSON, S., HAYES, A., DEBUSE, V., YORK, A. \& LEWIS, T. 2019. The response of cerambycid beetles (Coleoptera: Cerambycidae) to long-term fire frequency regimes in subtropical eucalypt forest. Austral Ecol. 44(4): 1-12.

EVANGELISTA NETO, J., OLIVEIRA, C.M., VAZ-DE-MELLO, F.Z. \& FRIZZAS, M.R. 2017. Diversity of Cetoniidae (Insecta: Coleoptera) in the Cerrado of Central Brazil. Entomol. Sci. 20: 1-9.

FELFILI, J.M. \& SILVA JÚNIOR, M.C. 2005. Diversidade alfa e beta no cerrado sensu strictu, Distrito Federal, Goiás, Minas Gerias e Bahia. In Cerrado: ecologia, biodiversidade e conservação (A. Scariot, J.C. Sousa-Silva \& J.M. Felfili, eds). Ministério do Meio Ambiente (MMA). Brasília.

FERNANDES, F.L., PICANÇO, M.C., CHEDIAK, M., FERNANDES, M.E.S., RAMOS, R.S. \& MOREIRA, S.S. 2010. A low-cost trap for Cerambycidae monitoring in forest plantations in Brazil. Pesqui. Agropecu. Bras. 45(9): 1044-1047. 
FERREIRA, A.S. \& ROCHA, A.A. 2015. Cerambycidae (Coleoptera) from Lagoa do Tamburí farm, Aracatu - Bahia, with new records. Pap. Avulsos Zool. 55(25): 363-371.

FRANKLIN, J. 2009. Mapping species distribution, spatial inference and prediction. Cambridge University Press, Cambridge, UK.

FRIZZAS, M.R., BATISTA, J.L.F.L., ROCHA, M.V.C. \& OLIVEIRA, C.M. 2020. Diversity of Scarabaeinae (Coleoptera: Scarabaeidae) in an urban fragment of Cerrado in Central Brazil. Eur. J. Entomol. 117: 273-281.

GALILEO, M.H.M. \& MARTINS, U.R. 2006. Cerambycidae (Coleoptera, Insecta) do Parque Copesul de Proteção Ambiental, Triunfo, Rio Grande do Sul, Brasil. Museu de Ciências Naturais da Fundação Zoobotânia do Rio Grande do Sul, 314p.

GARCIA, A.H. 1987. Ocorrência de escarabeídeos indicando a presença de larva de Macropophora accentifer (Oliver, 1975) em plantas cítricas. An. Esc. Agron. Vet. 17(1): 37-42.

GARCIA, A.H. \& NAKANO, O. 1984. Avaliação da atratividade do melaço de cana e proteína hidrolizada de milho na captura de coleobrocas em citrus. Laranja 5: 289-297.

GOTTSBERGER, G. 1988. The reproductive biology of primitive angiosperms. Taxon 37(3): 630-643.

HAJAR, N., ZAINAL, S., ATIKAH, O. \& TENGKU ELIDA, T.Z.M. 2012. Optimization of ethanol fermentation from pineapple peel extract using response surface methodology (RSM). Inter. J. Nutr. Food Engin. 6(12): 1102-1108.

HAMMER, O., HARPER, D.A.T. \& RYAN, P.D. 2001. PAST: Paleontological Statistics software package for education and data analysis. Paleontol. Electron. 4(1): 9. Version 3.20.

HANKS, M.L., MILLAR, G.J., MONGOLD-DIERS, J.A., WONG, J.C.H., MEIER, L.R., REAGEL, P.F. \& MITCHELL, R.F. 2012. Using blends of cerambycid beetle pheromones and host plant volatiles to simultaneously attract a diversity of cerambycid species. Can. J. Res. B 42: 1050-1059.

INTERNATIONAL UNION FOR CONSERVATION OF NATURE (IUCN). 2019. https://www.iucnredlist.org/ (last access in 17/07/2019).

JÁKL, S. 2009. Results of entomological expeditions to Yamdena, Larat, Tandula, Selaru and Molu islands (Indonesia, Moluccas, Tanimbar islands) with the description of new genus, three new species and four new subspecies (Coleoptera: Cetoniinae). Stud. Rep. District Museum Prague-East Taxon. Series 5(1-2): 139-158.

KLINK, C.A. \& MACHADO, R.B. 2005. A conservação do Cerrado brasileiro. Megadiversidade 1(1): 147-155.

KOVACH, W.L. 2011. Oriana - Circular Statistics for Windows, Version 4 Kovach Computing Services, Pentraeth.

LEMES, P.G., ANJOS, N.D. \& CORDEIRO, G. 2011. Injúrias e oviposição de Oncideres impluviata (Germar) (Col.: Cerambycidae) em Piptadenia gonoacantha (Mart.) Macbr. Comunicata Scientiae 2(1): 53-56.

MACHADO, L.A., HABIB, M., LEITE, L.G. \& MENDES, J.M. 2006. Estudos ecológicos e comportamentais de Migdolus fryanus (Westwood, 1863) (Coleoptera: Vesperidae), em cultura de cana-de-açúcar, em quatro municípios do estado de São Paulo. Arq. Inst. Biol. 73 (2): 227-233.

MACHADO, V.S., BOTERO, J.P., CARELLI, A., CUPELLO, M., QUINTINO, H.Y. \& SIMÕES, M.V.P. 2012. Host plants of Cerambycidae and Vesperidae (Coleoptera, Chrysomeloidea) from South America. Rev. Bras. Entomol. 56(2): 186-198

MAIA, A.C.D., IANUZZI, L., NOBRE, C.E.B. \& ABUQUERQUE, C.M.R. 2003. Padrões locais de diversidade de Cerambycidae (Insecta, Coleoptera) em vegetação de Caatinga. Editora Universitária da Universidade Federal de Pernambuco, Recife, p. 391-433.

MARINONI, R.C. \& GANHO, N.G. 2003. Sazonalidade de Nyssodrysina lignaria (Bates) (Coleoptera, Cerambycidae, Lamiinae), no Estado do Paraná, Brasil. Rev. Bras. Zool. 20(1): 141-152.

MENDOZA, C. 1994. A theorem for Rayleigh's method of dimensional analysis and it's proof. Mech. Res. Commun. 21(2): 103-107.
MITTERMEIER, R.A., GIL, P.R., HOFFMANN, M., PILGRIM, J., BROOKS, T., MITTERMEIER, C.G., LAMOREUX, J. \& FONSECA, G.A.B. 2005. Hotspots revisited: Earth's biologically richest and most threatened terrestrial ecoregions. Conservation International. p. 392

MONNÉ, M.A. 2005. Catalogue of the Cerambycidae (Coleoptera) of the Neotropical Region. Part I. Subfamily Cerambycinae. Zootaxa 946: 1-765.

MONNÉ, M.A. Catalogue of the Cerambycidae (Coleoptera) of the Neotropical Region. 2020a. https://cerambycids.com/catalog (last access in 15/06/2020).

MONNÉ, M.A. Cerambycidae in Catálogo Taxonômico da Fauna do Brasil. PNUD. 2020b. http://fauna.jbrj.gov.br/fauna/faunadobrasil/109859 (last access in 03/11/2020)

MONNÉ, M.L. \& MONNÉ, M.A. 2006. Revisão do gênero Tomrogersia Fragoso (Coleoptera, Cerambycidae). Rev. Bras. Zool. 23(4): 1196-1198.

MONNÉ, M.L. \& MONNÉ, M.A. 2017. New species and new records of Cerambycidae (Insecta, Coleoptera) from RPPN Sanctuary of Caraça, Minas Gerais, Brazil. Zootaxa 4319(2): 201-262.

MYERS, N., MITTERMEIER, R.A., MITTERMEIER, C.G., FONSECA, G.A.B. \& KENT, J. 2000. Biodiversity hotspots for conservation priorities. Nature 403: 853-858.

NAPP, D.S. \& MONNÉ, M.A. 2006. Novas espécies de Mecometopus Thomson, (Coleoptera, Cerambycidae). Rev. Bras. Entomol. 50(1): 39-42.

OLIVEIRA, C.M. \& FRIZZAS, M.R. 2008. Insetos de Cerrado: distribuição estacional e abundância. Embrapa Cerrados, Planaltina. Boletim de Pesquisa e Desenvolvimento, 216, Embrapa Cerrados.

OLIVEIRA, C.M. \& FRIZZAS, M.R. 2017. How climate influences the biology and behaviour of Phyllophaga capillata (Coleoptera: Melolonthidae) in the Brazilian Cerrado. Austral Entomol. 58(2): 336-345.

OROZCO, J. 2012. Monographic revision of the American genus Euphoria Burmeister, 1842 (Coleoptera: Scarabaeidae: Cetoniinae). Coleopts. Bull. 11: 1-182.

PACHECO, F.C., DELOYA, C. \& CORTES, G.P. 2006. Phytophagous scarab beetles from the Central Region of Guerrero, Mexico (Coleoptera: Scarabaeidae: Melolonthinae, Rutelinae, Dynastinae, Cetoniinae). Rev. Colomb. Entomol. 32(2): 191-199.

PINHEIRO, F., DINIZ, I.R., COELHO, D. \& BANDEIRA, M.P.S. 2002. Seasonal pattern of insect abundance in the Brazilian Cerrado. Austral Ecol. 27(2): 132-136

PREVEDELLO, J.A. \& CARVALHO, C.J.B. 2006. Conservação do Cerrado Brasileiro: o método pan-biogeográfico como ferramenta para a seleção de áreas prioritárias. Nat. Conservação 4(1): 39-57.

PROGRAMAECOLÓGICO DE LONGADURAÇÃO (PELD). Áreas de estudo. http://www.peld.unb.br/index.php?option=com_content\&view=article\&id $=8 \&$ Itemid $=10$ (last access in 26/06/2018)

PUKER, A., AD'VINCULA, H.L., KORASAKI, V., FERREIRA, F.N.F. \& OROZCO, J. 2014. Biodiversity of Cetoniinae beetles (Coleoptera: Scarabaeidae) in introduced and native habitats in the Brazilian Atlantic Forest. Entomol. Sci. 17: 309-315.

RAMOS, D.L., CUNHA, W.L., EVANGELISTA, J., LIRA, L.A., ROCHA, M.V.C., GOMES, P.A., FRIZZAS, M.R. \& TOGNI, P.H.B. 2020. Ecosystem services provided by insects in Brazil: What do we really know? Neotrop. Entomol. https://doi.org/10.1007/s13744-020-00781-y (last acess in 27/07/2020).

RODRIGUES, S.R., OLIVEIRA, J.L.N., BAGNARA, C.A.C. \& PUKER, A. 2013. Cetoniinae (Coleoptera: Scarabaeidae) attracted to fruit baited traps near Aquidauana, Mato Grosso do Sul, Brazil. Coleopts. Bull. 67: 119-122.

SAKALIAN, V. \& GEORGIEV, G. 2011. Contribution to the knowledge of longhorn beetles (Coleoptera, Cerambycidae) from Kenya. Biodiversity Journal 2(2): 67-72.

SANO, E.E., ROSA, R., BRITO, J.L.S. \& FERREIRA, L.G. 2010. Land cover mapping of the tropical savanna region in Brazil. Environ. Monit. Assess. 166: $113-124$. 
SANTOS, A., ZANETTI, R., ALMADO, R.P. \& ZANUNCIO, J.C. 2014 Cerambycidae associated with hybrid Eucalyptus urograndis and native vegetation in Carbonita, Minas Gerais state, Brazil. Fla. Entomol. 97(2): 522-527.

SCHMEELK, T.C., MILLAR, J.G. \& HANKS, L.M. 2016. Influence of trap height and bait type on abundance and species diversity of Cerambycidae beetles captured in forests of east-central Illinois. J. Econ. Entomol. 109(4): 1750-1757.

SILVA, D.P., AGUIAR, A.G. \& SIMÃO-FERREIRA, J. 2016. Assessing the distribution and conservation status of a long-horned beetle with species distribution models. J. Insect Conserv. 20: 611-620.

SILVA, F.A.M., ASSAD, E.D. \& EVANGELISTA, B.A. 2008. Caracterização climática do bioma Cerrado. In Cerrado: Ecologia e Flora (S.M. Sano, S.P. Almeida \& J.F. Ribeiro, eds). Embrapa Cerrados e Embrapa Informação Tecnológica, Brasília. p. 69-88.

SILVA, N.A.P., FRIZZAS, M.R. \& OLIVEIRA, C.M. 2011. Seasonality in insect abundance in the Cerrado of Goiás State, Brazil. Rev. Bras. Entomol. 55(1): 79-87.

SOUZA, D.S. \& SILVA, A.A. 2012. Cerambycidae (Insecta: Coleoptera) of the Parque Natural Municipal de Porto Velho, Rondônia, Western Amazon, Brazil. Biota Neotrop. 12(1). http://www.biotaneotropica.org.br/ v12n1/ en/abstract?inventory+bn01112012012.
TAVAKILIAN, G. \& CHEVILLOTTE, H. 2020. Base de données Titan sur les Cerambycidés ou Longicornes. http://titan.gbif.fr/ (last access in 19/06/2020).

TILMAN, D., CASSMAN, K.G., MATSON,P.A., NAYLOR, R. \& POLASKY, S. 2002. Agricultural sustainability and intensive production practices. Nature 418: 671-677.

WOLDA, H. 1978. Seasonal fluctuations in rainfall, food and abundance of tropical insects. J. Anim. Ecol. 47(2): 369-381.

WONG, J.C.W. \& HANKS, L.M. 2016. Influence of fermenting bait and vertical position of traps on attraction of Cerambycidae beetles to pheromone lures. J. Econ. Entomol. 109(5): 2145-2150.

ZACCA, T. \& BRAVO, F. 2012. Borboletas (Lepidoptera: Papilionoidea e Hesperioidea) da porção norte da Chapada Diamantina, Bahia, Brasil. Biota Neotrop. 12(2). http:// www.biotaneotropica.org.br/v12n2/pt/abstract?inventory+bn00212022012.

ZANUNCIO, J.C., PIRES, E.M., ALMADO, R.P., ZANETTI, R., MONNÉ, M.A., PEREIRA, J.M.M. \& SERRÃO, J.E. 2009. Damage assessment and host plant records of Oxymerus basalis (Dalman, 1823) (Cerambycidae: Cerambycinae: Trachyderini) in Brazil. Coleopts. Bull. 63(2): 179-181.

Received: 04/08/2020

Revised: 05/11/2020

Accepted: 20/11/2020

Published online: 22/01/2021 